RESIDENT

\& FELLOW

SECTION

Section Editor

Mitchell S.V. Elkind,

MD, MS

Roman Schniepp, MD

Berend Feddersen, MD,

$\mathrm{PhD}$

Address correspondence and reprint requests to Dr. Berend Feddersen, Department of Neurology, Klinikum Grosshadern, University of Munich, Marchioninistr. 15, 81377 München, Germany berend.feddersen@med.uni-muenchen.de

\title{
Teaching Video NeuroImages: Oculo-risorius phenomenon
}

吕

We present a patient who was admitted to our hospital with complaints of intermittent diplopia, with incidental involuntary contraction of the muscles for elevation of both corners of the mouth during maximal lateral gaze (see video on the Neurology ${ }^{\circledR}$ Web site at www.neurology.org). This is a variation of the oculo-auricular phenomenon (OAP), which represents a central connection between the oculomotor structures in the brainstem (superior colliculus, pontine paramedian reticular formation) and the bilateral facial nuclei (retroauricular muscles). ${ }^{1}$ In lower mammals, abduction of the eyes leads to flattening of the ear in order to provide a sufficient lateral field of view. This provides a quick orientation of the visual and auditory system to targets. In humans, the synchronization of eye and ear movements is an evolutionary relict, but in addition to selected brainstem reflexes like the masseter and the blink reflex, it can provide a helpful tool in the topodiagnosis of brainstem lesions. ${ }^{2}$

We assume that in our case the activation of the risorius and zygomatic muscles is due to a persistent OAP. This central phenomenon should be distinguished from facial synkinesis, which is a peripheral phenomenon due to a cross-activation of 2 different peripheral branches of the facial nerve, such as eye closure with volitional movement of the mouth.

\section{REFERENCES}

1. Wilson SAK. A note on an associated movement of the eyes and ears in man. Rev Neurol Psychiatry 1908;6:331336.

2. Urban PP, Marczynski U, Hopf HC. The oculo-auricular phenomenon: findings in normals and patients with brainstem lesions. Brain 1993;16:727-738. 


\title{
Neurology
}

\author{
Teaching Video NeuroImages: Oculo-risorius phenomenon \\ Roman Schniepp and Berend Feddersen \\ Neurology 2011;76; e42 \\ DOI 10.1212/WNL.0b013e31820f2d55
}

This information is current as of March 7, 2011

\section{Updated Information \&}

Services

Supplementary Material

References

Subspecialty Collections

Permissions \& Licensing

Reprints including high resolution figures, can be found at:

http://n.neurology.org/content/76/10/e42.full

Supplementary material can be found at:

http://n.neurology.org/content/suppl/2011/03/06/76.10.e42.DC1

This article cites 2 articles, 0 of which you can access for free at: http://n.neurology.org/content/76/10/e42.full\#ref-list-1

This article, along with others on similar topics, appears in the following collection(s):

Clinical neurology examination

http://n.neurology.org/cgi/collection/clinical_neurology_examination Ocular motility

http://n.neurology.org/cgi/collection/ocular_motility

Information about reproducing this article in parts (figures,tables) or in its entirety can be found online at:

http://www.neurology.org/about/about_the_journal\#permissions

Information about ordering reprints can be found online:

http://n.neurology.org/subscribers/advertise

Neurology ${ }^{\circledR}$ is the official journal of the American Academy of Neurology. Published continuously since 1951, it is now a weekly with 48 issues per year. Copyright Copyright (? 2011 by AAN Enterprises, Inc.. All rights reserved. Print ISSN: 0028-3878. Online ISSN: 1526-632X.

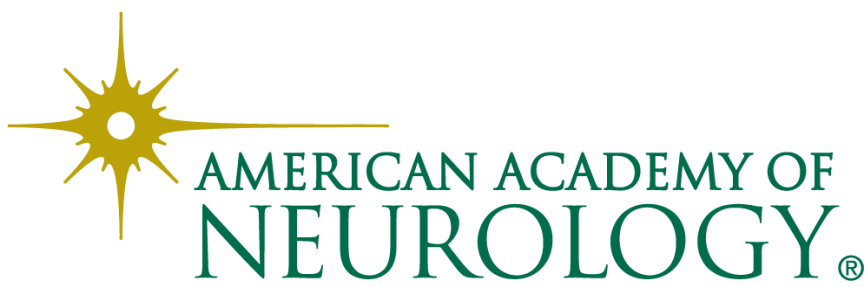

